\title{
Influence of the moisture at harvest and drying process of the grains on the level of carotenoids in maize (Zea mays)
}

\author{
Wilton Soares CARDOSO ${ }^{1}$, Aluízio BORÉM ${ }^{2}$, Décio KARAM ${ }^{3}$, Sara de Almeida RIOS ${ }^{4}$, Maria Cristina Dias PAES ${ }^{3 *}$
}

\begin{abstract}
Maize is considered a source of carotenoids; however, these compounds are highly unstable, degraded by high temperatures, exposure to light and presence of oxygen. The objective of this work was to evaluate the influence of the moisture and type of drying applied to grains on the level of carotenoids in yellow maize. The experiment was conducted in a completely randomized design ( $2 \times 4$ factorial), two levels of initial moisture at the harvest (22 and 19\%) and three types of drying (in the sun; in the shade and in a dryer) and control (no drying). The samples of grains after drying with $12 \%$ of final moisture were analyzed by concentration of total carotenoids, carotenes ( $\alpha$-carotene $+\beta$-carotene), monohydroxilated carotenoids ( $\beta$-cryptoxanthin), and xanthophylls (lutein + zeaxanthin). Initial moisture, type of drying and the interaction between moisture versus drying influence $(p \leq 0.05)$ the levels of carotenoids in grains. This is the first report about the drying conditions and harvest's initial moisture as influence on the profile and content of carotenoids in maize grains. Based on the results, this work suggested that the harvest be carried out preferably when the grains present $22 \%$ humidity, with drying in a dryer or in shade for further use or storage.
\end{abstract}

Keywords: cereals; carotenes; vitamins; biofortification; food preservation and processing.

Practical Application: Assessment of the effects of post-harvest on nutrient, especially in the harvesting grain.

\section{Introduction}

Carotenoids are indispensable for human nutrition and health (Zhou et al., 2011). Interest in dietary carotenoids comes from their precursors of vitamin $\mathrm{A}$, antioxidant properties and the association between carotenoid deficiencies and many chronic human diseases (Burt et al., 2011, 2013). Breeding to increase $\beta$-carotene levels in cereal grains, termed provitamin A biofortification, is an economical approach to address dietary vitamin A deficiency in the developing world (Owens et al., 2014).

Maize is considered a source of carotenoids, substances that are important for human health, given the capability as antioxidant and the activity as vitamin A precursor of some of these compounds (Rodriguez-Amaya, 2001; Vallabhaneni \& Wurtzel, 2009). The variability in the concentration of carotenoids in grains have been observed in maize cultivars and inbred lines, making the increase of concentration these compounds in the edible part of the plant possible by genetic improvement, especially of those of biological significance, provitamin A carotenoids (pVAC), precursors of vitamin A (Janick-Buckner et al., 1999; Kurilich \& Juvik, 1999; Cardoso et al., 2009).

The main carotenoids found in the chromoplasts of maize endosperm are classified as xanthophylls (lutein, zeaxanthin and $\beta$-cryptoxanthin) and carotenes ( $\beta$-carotene, $\alpha$-carotene, and $\beta$-zeacarotene) (Janick-Buckner et al., 1999). The xanthophylls lutein and zeaxanthin were major carotenoid species in maize milled fractions, accounting for $70 \%$ of total carotenoid content
(Kean et al., 2008). In the kernel most of the carotenoids are associated with endosperm tissue. Total carotenoid concentration in corn belt dent (CBD) germplasm ranges from 0.15 to $51.4 \mu \mathrm{g} \mathrm{g}^{-1}$ dry weight (DW), with $\beta$-carotene ranging from 0.07 to $7.64 \mu \mathrm{g} \mathrm{g}^{-1} \mathrm{DW}$, $\beta$-cryptoxanthin from 0.07 to $4.9 \mu \mathrm{g} \mathrm{g}^{-1} \mathrm{DW}$, lutein from 0.00 to $27.59 \mu \mathrm{g} \mathrm{g}^{-1} \mathrm{DW}$, and zeaxanthin from 0.01 to $30.7 \mu \mathrm{g} \mathrm{g}^{-1} \mathrm{DW}$ (Kurilich \& Juvik, 1999; Egesel et al., 2003). The distribution of carotenoids in the grain of dry dent corn is $74 \%$ to $86 \%$ in the vitreous endosperm, $9 \%$ to $23 \%$ in the farinaceous endosperm, $2 \%$ to $4 \%$ in the germ and $1 \%$ in the pericarp (Blessin et al., 1963).

The light absorption properties of carotenoids derive from the presence of its chromophore group, the polienic chain (Britton et al., 1995). A chromophore of seven or more conjugated double bonds grants the ability to absorb light in the visible region, giving them a colouration from yellow to red. The polienic system also gives the molecule a high susceptibility to oxidative degradation and to geometrical isomerization caused by light, heat or acids. Thus, the strong antioxidant power of carotenoids is the main responsible for its easy degradation by temperature, light or oxygen (Rodriguez-Amaya, 2001; Ambrósio et al., 2006; Boon et al., 2010). This is a challenge for an improvement program for biofortification (Bouis et al., 2011), which, in addition to the seed, must generate biofortified derived products, overcoming the losses that may occur in the processes of harvest and postharvest. 
There are few reports quantifying the possible losses related to carotenoid pigments, despite factors such as oxygen, temperature and light, present in the harvest and in the drying of seeds and grains of maize (Burt et al., 2010; Moura et al., 2015). More research is needed to recommend the best drying method for maize (Moura et al., 2015).

Therefore, the objective of this study was to evaluate the influence of different levels of moisture in the harvest and of the type of drying on the concentration of the main carotenoids present in grains of yellow maize.

\section{Materials and methods}

\subsection{Corn growing conditions}

Grains of the simple hybrid BRS 1001 produced in the experimental fields of Embrapa Maize and Sorghum - CNPMS, in the city of Sete Lagoas, Minas Gerais (19 $28^{\prime}$ south latitude, $44^{\circ} 15^{\prime} 8^{\prime \prime}$ west longitude from Greenwich and altitude of $732 \mathrm{~m}$ ) were utilized. The cultivation was carried out using the system of tillage, with mechanized fertilization in the seeding of $300 \mathrm{~kg} \cdot \mathrm{ha}^{-1}$ NPK (formulated 8:28:16 + 0.3 Zinc) and in the top-dressing fertilization with $80 \mathrm{~kg} \cdot \mathrm{ha}^{-1}$ of urea. The management of the soil's top-dressing was performed using application of the desiccant glyphosate at a dose of 3 L.ha- ${ }^{-1}$. In the post-emergence, the herbicide Nicosulfuram was used for weed control. The pest control obeyed the integrated management recommended for the culture. The hybrid BRS 1001 was chosen because it is a cultivar with high levels of carotenes (Cardoso et al., 2009).

\subsection{Sample preparation}

Maize ears were collected in a single experimental portion of $1,000 \mathrm{~m}^{2}$, with a space of $70 \mathrm{~cm}$ between rows and seven plants per meter, in a total of approximately 60,000 plants. ha-1. The physiological maturity and grain moisture were monitored weekly. To start the daily monitoring of the percentage of moisture in the maize at the field, a rate of $50 \%$ of ears at the peak of maturation (50-60 days after flowering) was used, characterized by the formation of a black layer between the grains and its insertion in the ears.

The experiment was conducted in a completely randomized design in a $2 \times 4$ factorial scheme, with two levels of grain moisture in the harvest (19 and 22\%) and four types of drying: (1) control without drying; (2) drying in the sun; (3) drying in the shade ( $80 \%$ of shading); (4) drying in a dryer of the type "fixed bed", with three repetitions of 8 ears.

The monitoring of the grain moisture up to $22 \%$ and then $19 \%$ was made daily, where 10 ears were taken at random in the field and after the withdrawal and randomization of grain was preparing a sample, which had verification of its moisture through the apparatus Moisture Meter Dickey John MULTIGRAIN (Minneapolis - USA). When the humidity of $22 \%$ was achieved, were harvested 60 ears randomly throughout the field. This part was separated for moisture confirmation analysis and the other followed for drying treatments. The same procedure was repeated when the humidity reached $19 \%$.
The drying in the sun was performed arranging the ears on iron screens suspended $5 \mathrm{~cm}$ from the soil, under a minimum photoperiod of 10 hours. The drying in the shade was performed using the same procedures of the drying in the sun, with a netshade providing $80 \%$ of shading. At night, the screens were kept in a warehouse for protection against rain, dew and animals. The drying in an oven was conducted in an air-circulating equipment model 420/7D (Nova Ética - Vargem Grande Paulista - São Paulo, Brazil) at a temperature of $35^{\circ} \mathrm{C}$. All types of drying were applied to husked ears.

Controlled position rearrangements were carried out in order to homogenize the drying conditions. Moreover, monitoring of the ambient temperature of the three types of drying was performed, with three to four daily measurements with thermometers to identify possible temperature variations throughout the day. Additionally, the relative humidity and maximum and minimum temperatures at the Embrapa Maize and Sorghum in Sete Lagoas - MG were registered daily.

For the monitoring of grain moisture during the drying, two rows of grains from three ears, randomly selected within the experimental portion, were used. The monitoring of the grain moisture was through the apparatus Moisture Meter Dickey John MULTIGRAIN (Minneapolis - USA). The moisture content was yet confirmed using a $103^{\circ} \mathrm{C}$ convection oven method (Approved Method 44-15A - American Association of Cereal Chemists, 2000). When humidity reached $12 \%$, the drying process was interrupted and the material threshed in a semi-manual thresher (HÄDRICH - Montenegro/Rio Grande do Sul), which generated a sample composed of grains from the eight ears per repetition. To this sample, quartering was applied to obtain a final mass of $60 \mathrm{~g}$, which was sent for subsequent grinding and chemical analysis. The quartering procedure was performed to the total sample of homogenized grains arranged in a clean, round surface. From the circle divided into quarters, two opposite quarters were selected, whose grains were again homogenized and quartered, repeating the procedure until reaching a final, predetermined amount of sample. These samples were ground in a cyclone micro-mill, model MA 020, connected, with a $0.5 \mathrm{~mm}$ screen (MARCONI - Piracicaba - SP). Then the samples were kept in glass flasks with protection from light and stored in a freezer at $-18^{\circ} \mathrm{C}$ for further chemical analysis.

\subsection{Carotenoid analysis}

The analysis of the composition of carotenoids in maize was performed by the spectrophotometric-chromatographic method described by Rodriguez-Amaya \& Kimura (2004). The analyses were conducted in doubles, with the obtention of the concentrations of total carotenoids and carotenes fractions $(\alpha+\beta$-carotene $)$, xanthophylls (lutein + zeaxanthin $)$, and monohydroxilated ( $\beta$-cryptoxanthin), expressed in $\mu \mathrm{g} \cdot \mathrm{g}^{-1}$. In addition, the percentage of reduction of carotenoids in relation to the control without drying was quantified as well, with the following formula: $\%$ reduction $=($ median of control treatment fraction - median of drying treatment fraction)* $100 /$ (median of control treatment fraction). 


\subsection{Statistical analysis}

The data obtained were subjected to analysis of variance (ANOVA), followed by an application of the Tukey's test for the comparison of medians, when detected significance for the F-test at 5\% probability, using the statistical program SAEG/9.1 (Fundação Arthur Bernardes, 2007).

\section{Results and discussion}

The median concentrations of total carotenoids, carotenes and xanthophylls in harvested grains with $22 \%$ moisture were significantly higher than those of grains with $19 \%$ moisture $(\mathrm{p}<0.05)$ (Table 1). This tendency was not observed for the concentration of beta-cryptoxanthin (monohydroxilated carotenoid). Possibly, heat exposure during the stay of the ears in the field, until reaching the optimal harvest moisture (18-20\%) (Mantovani, 2010), favored the reduction in the concentration of carotenoids in the grains of maize.

These results are in agreement with the findings of Xu et al. (2010), where total carotenoids first decreased, then increased, and then decreased to minimum at maturity stage. Analysis of the main carotenoid compounds showed that lutein first increased and then decreased $(\mathrm{p}<0.05)$, whereas the reverse was found for $\beta$-cryptoxanthin. The change in zeaxanthin was consistent with total carotenoids.

The accumulation of carotenoids in maize grains occurs during the endosperm's development (Bartley \& Scolnik, 1995) and starts 10 to 15 days after pollination (DAP) with the maximum concentration of 20 to 25 DAP, depending on the variety and environmental conditions (Wurtzel, 2004). Nevertheless, Kurilich \& Juvik (1999) suggested that the concentration of carotenoids depends on the maturity of the endosperm, and that there is an increase mainly in the concentration of $\beta$-cryptoxanthin and lutein. In general, the biosynthesis of carotenoids occurs until the point of physiological maturation, after which there is a concentration of carotenoids in the grain resulting from the loss of water. However, the data from this experiment showed that there may be a reduction in the level of some carotenoids fractions, probably due to differences in their antioxidant capacity. Cantrell et al. (2003) reported an increased antioxidant efficiency of hydrocarbonated carotenoids in relation to xanthophylls. Moreover, the lowest level may be related to a decrease in the biosynthesis of carotenoids and not to their degradation, especially considering that the synthesis of these compounds is mediated by light (Simkin et al., 2003; Briggs et al., 2007), and that the ears in the field were protected by the straw.

Possible enzymatic reactions responsible for the lower content of carotenoids in the initial moisture of 19\% could is on the formation of abscisic acid (ABA). The connection between carotenoids and ABA was supported by analysis of maize mutants with reduced color levels in the endosperm and ABA (Fong et al., 1983; Schwartz et al., 1997). Zeaxanthin is a precursor in the formation of epoxides carotenoids that are degraded by enzymes breaking, as NCED (9-cis-epoxycarotenoid dioxygenases), to ABA (DellaPenna \& Pogson, 2006). Several breaking enzymes responsible for degradation of these carotenoids for the production of abscisic acid are isolated from maize (Schwartz et al., 1997).

The interaction between the factors moisture in the harvest and type of drying was significant for the variables total carotenoids, carotenes and xanthophylls in maize grains $(\mathrm{p}<0.05)$, which was not observed for the concentration of $\beta$-cryptoxanthin, influenced only by the type of drying. Bechoff et al. (2009) suggested that there is a linkage between both initial dry matter and initial carotenoid content and percentage loss carotenoid during drying.

In the evaluation of the effects of different types of drying, the greatest loss of carotenoids was observed in grains subjected to the drying in the sun. This result was expected, since carotenoids are highly susceptible to oxidative degradation and geometrical isomerization caused by light (Britton et al., 1995). The degradation of all-trans- $\beta$-carotene during drying are

Table 1. Concentration of total carotenoids, carotenes, monohydroxilated carotenoids and xanthophylls in maize grains 'BRS1001' harvested with different percentages of moisture (22 and 19\%) and submitted to different types of drying (sun, shade, and dryer). Embrapa Maize and Sorghum, Sete Lagoas, Minas Gerais, 2007.

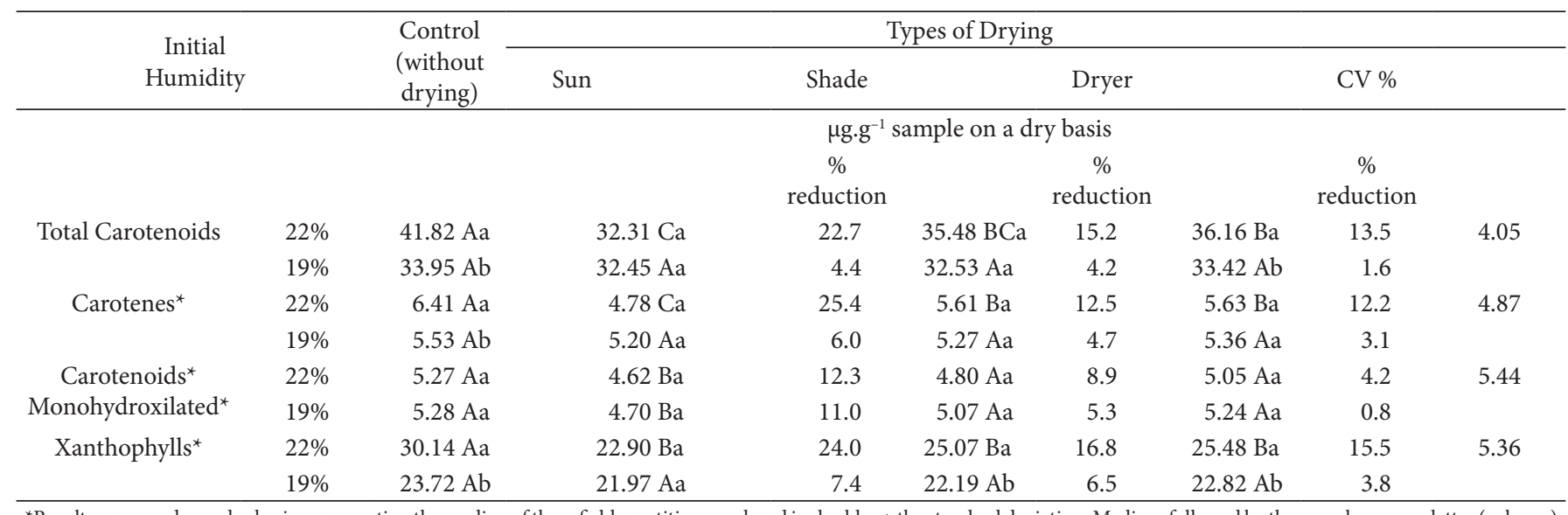

${ }^{\star}$ Results expressed on a dry basis, representing the median of three field repetitions analyzed in doubles + the standard deviation. Medians followed by the same lowercase letter (column) and the same capital letter (line) do not differ by the Tukey's test at $5 \%$ probability. 
probably caused by oxidative degradation which is promoted by the presence of oxygen, high temperature, low water activity and the presence of light, while isomerization appeared to have a minimum effect on degradation during the drying process (Bechoff et al., 2010). In Burt et al. (2010) the pVAC retention in maize after drying, showing that high heat $\left(90^{\circ} \mathrm{C}\right)$ was not more detrimental than low heat (above $25 \mathrm{C}^{\circ}$ ) when maize was dried in the oven. Nevertheless, there was no loss in total carotenoids, carotenes and xanthophylls for grains harvested in $19 \%$ moisture, which may have occurred because of the lower presence of water in these grains, a factor directly related to the degradation of carotenoids by the reduction of oxidation reactions (Britton, 1992; Rodriguez-Amaya, 2001), and also less time needed for drying them until the final moisture of $12 \%$

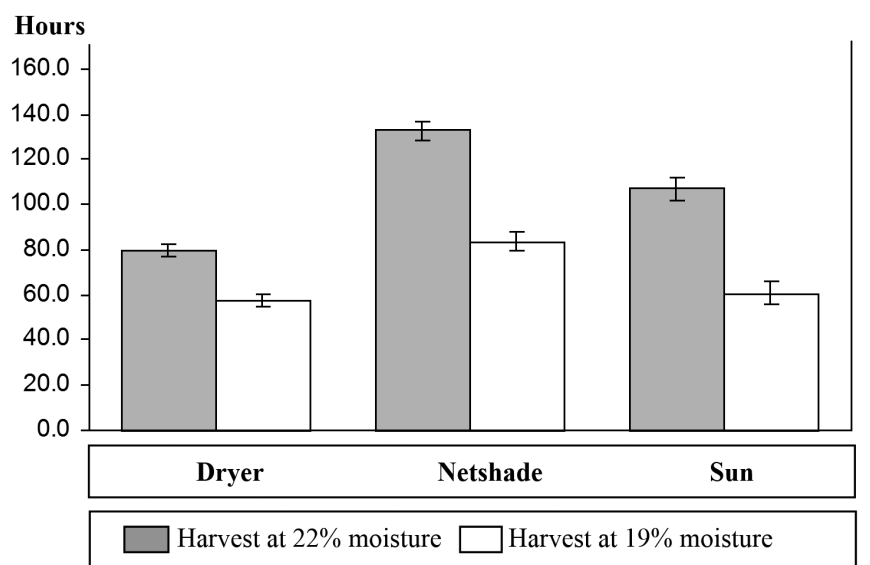

Figure 1. Average time (+/- standard error) in hours required for drying maize grains to $12 \%$ moisture, under three different drying conditions (sun, under shade with a netshade of $80 \%$ shading, and dryer). Embrapa Maize and Sorghum. Sete Lagoas, Minas Gerais.
(Figure 1). As grains harvested in moisture 22\% have higher levels of total carotenoids, carotenes and xanthophylls, this corroborates the observations of Bengtsson et al. (2008) that suggested for an equivalent drying time, cultivars with higher moisture content and with higher initial carotenoid content tend to lose more carotenoids during the drying process.

Probably, the drying time had greater influence on the loss of these compounds, despite the maximum and minimum temperature and relative moisture, which were similar during all the drying period after the harvest (Figure 2). The higher temperature-short time combination rather than low temperature-longer time resulted in higher pVAC retention in sweet potato (Bengtsson et al., 2008; Bechoff et al., 2009) and maize (Burt et al., 2010).

As the concentration of $\beta$-cryptoxanthin was not altered by the grains drying, regardless of the initial moisture, there seems to be an influence of each carotenoid's structure on this response.

A higher decrease of xanthophylls after the drying of grains was observed. When correlating it to the antioxidant properties of lutein, which helps fight the seed aging fighting free radicals and reactive oxygen species, leading to consequent reduction of this compound in the seed (Pinzino et al., 1999). Thus, it is suggested that lutein is the main carotenoid acting as an antioxidant after the physiological maturation of the grain.

The concentrations of total carotenoids and xanthophylls were significantly different and higher for the drying in the dryer, to grains harvested with $22 \%$ moisture (36.78 and $26 \mu \mathrm{g} . \mathrm{g}^{-1}$ ), compared with those harvested with $19 \%$ moisture (33.72 and $\left.23.04 \mu \mathrm{g} . \mathrm{g}^{-1}\right)(\mathrm{p}<0.05)$. In the shade drying, using a netshade, this difference was not detected for total carotenoids, with an overall median of $34.65 \mu \mathrm{g} . \mathrm{g}^{-1}$. However, the concentration of xanthophylls was higher $\left(25.28 \mu \mathrm{g} . \mathrm{g}^{-1}\right)$ for maize grains harvested with an initial $22 \%$ moisture compared with those

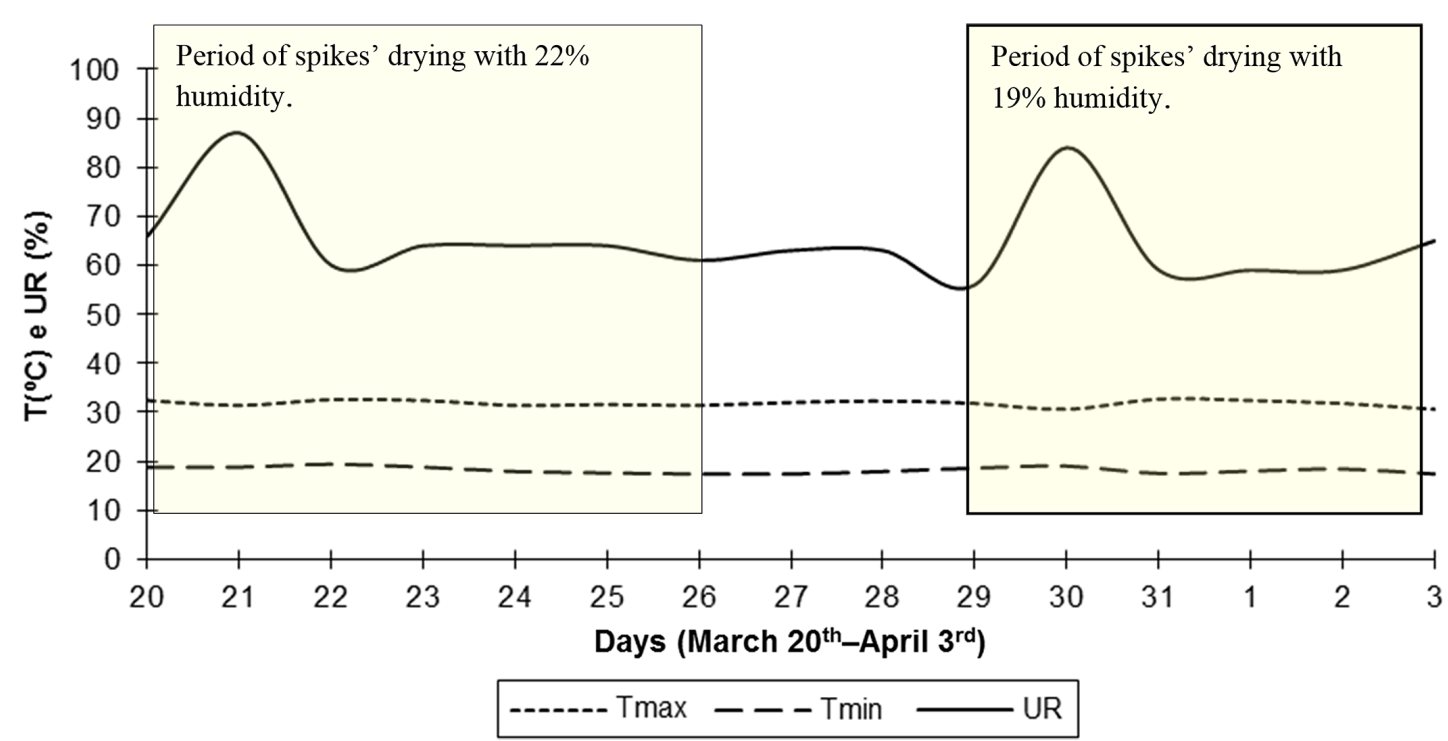

Figure 2. Minimum and maximum temperatures and relative humidity of the drying period of the spikes at 22 and $19 \%$, in tests carried out from March 20 to April 3, 2007. 
harvested at $19 \%$ moisture $\left(23.01 \mu \mathrm{g} . \mathrm{g}^{-1}\right)(\mathrm{p}<0.05)$. Sun drying caused no change in the concentration of total carotenoids and xanthophylls, independently of grain moisture in the harvest, with an overall median of 32.62 and $22.60 \mu \mathrm{g} \cdot \mathrm{g}^{-1}$, respectively, for total carotenoids and xanthophylls.

As total carotenoids include fractions of carotenes, monohydroxilated carotenoids, and xanthophylls, and as xanthophylls present the greatest proportion of carotenoids in the grains, it was expected that the influence of the drying conditions on total carotenoids and xanthophylls were similar, which was confirmed by the results. However, the levels of carotenes and monohydroxilated carotenoids were not affected by the drying conditions in the shade and in the dryer, with no significant differences $(p<0.05)$ among the medians of these treatments.

Considering the sun drying as the one with the highest rate of reduction in the concentration of carotenoids in the maize grains, based on the initial $22 \%$ moisture in the harvest, an inference can be made, by analyzing Table 1 , that this process results in reductions of $22 \%, 25 \%, 12 \%$, and $24 \%$ in the concentrations of total carotenoids, carotenes, monohydroxilated carotenoids and xanthophylls, respectively.

\section{Conclusions}

The levels of total carotenoids, carotenes and xanthophylls in grains of yellow maize are higher when they are harvested at $22 \%$ moisture in relation to those at $19 \%$ moisture.

The drying applied to maize grains promotes significant reductions in the concentrations of total carotenoids, carotenes and xanthophylls in grains harvested at $22 \%$ moisture, unlike in those harvested at $19 \%$ moisture.

For lower losses of carotenoids in maize the harvest must be carried out preferably when the grains present $22 \%$ humidity, followed by drying in a dryer or in the shade for further use or storage of the material as food for animal or human consumption.

\section{Acknowledgements}

Harvest Plus, Embrapa Maize and Sorghum, Federal Institute of Espírito Santo, and FAPEMIG for the financial support.

\section{References}

Ambrósio, C. L. B., Campos, F. A. C. S., \& Faro, Z. P. (2006). Carotenoides como alternativa contra a hipovitaminose A. Revista de Nutrição, 19(2), 233-243. http://dx.doi.org/10.1590/S1415-52732006000200010.

American Association of Cereal Chemists - AACC. (2000). Approved methods of the American Association of Cereal Chemists (10th ed., Approved Method, 44-15A). St. Paul: AACC.

Bartley, G. E., \& Scolnik, P. A. (1995). Plant carotenoids: pigments for photoprotection, visual attraction, and human health. The Plant Cell, 7(7), 1027-1038. http://dx.doi.org/10.1105/tpc.7.7.1027. PMid:7640523.

Bechoff, A., Dhuique-Mayer, C., Dornier, M., Tomlins, K., Boulanger, R., Dufour, D., \& Westby, A. (2010). Relationship between the kinetics of $\beta$-carotene degradation and formation of norisoprenoids in the storage of dried sweet potato chips. Food Chemistry, 121(2), 348-357. http://dx.doi.org/10.1016/j.foodchem.2009.12.035.
Bechoff, A., Dufour, D., Dhuique-Mayer, C., Marouzé, C., Reynes, M., \& Westby, A. (2009). Effect of hot air, solar and sun drying treatments on provitamin A retention in orange-fleshed sweet potato. Journal of Food Engineering, 92(2), 164-171. http://dx.doi.org/10.1016/j. jfoodeng.2008.10.034.

Bengtsson, A., Namutebi, A., Alminger, M. L., \& Svanberg, U. (2008). Effects of various traditional processing methods on the all-trans$\beta$-carotene content of orange-fleshed sweet potato. Journal of Food Composition and Analysis, 21(2), 134-143. http://dx.doi.org/10.1016/j. jfca.2007.09.006.

Blessin, C. W., Brecher, J. D., \& Dimler, R. J. (1963). Carotenoids of corn and sorghum. V. Distribution of xanthophylls and carotenes of yellow dent corn. Cereal Chemistry, 40, 582-586.

Boon, C. S., McClements, D. J., Weiss, J., \& Decker, E. A. (2010). Factors influencing the chemical stability of carotenoids in foods. Critical Reviews in Food Science and Nutrition, 50(6), 515-532. http://dx.doi. org/10.1080/10408390802565889. PMid:20544442.

Bouis, H. E., Hotz, C., McClafferty, B., Meenakshi, J. V., \& Pfeiffer, W. H. (2011). Biofortification: a new tool to reduce micronutrient malnutrition. Food and Nutrition Bulletin, 32(Suppl. 1), S31-S40. PMid:21717916.

Briggs, W., Tseng, T. S., Cho, H. T., Swartz, T. E., Sullivan, S., Bogomolni, R. A., Kaiserli, E., \& Christie, J. M. (2007). Phototropins and their LOV domains: versatile plant blue-light receptors. Journal of Integrative Plant Biology, 49(1), 4-10. http://dx.doi.org/10.1111/j.17447909.2006.00406.x.

Britton, G. (1992). Carotenoids. In G. F. Hendry (Ed.), Natural foods colorants (pp 141-148). New York: Blackie.

Britton, G., Liaaen-Jensen, S., \& Pfander, H. (1995) Carotenoids today and challenges for the future. In G. Britton, S. Liaaen-Jensen \& H. Pfander. Carotenoids (pp. 13-26). Berlin: Birkhäuser Verlag.

Burt, A. J., Caston, L., Leeson, S., Shelp, B. J., \& Lee, E. A. (2013). Development and Utilization of high carotenoid maize germplasm: proof of concept. Crop Science, 53(2), 554-563. http://dx.doi. org/10.2135/cropsci2012.02.0069.

Burt, A. J., Grainger, C. M., Smid, M. P., Shelp, B. J., \& Lee, E. A. (2011). Allele Mining of exotic maize germplasm to enhance macular carotenoids. Crop Science, 51(3), 991-1004. http://dx.doi.org/10.2135/ cropsci2010.06.0335.

Burt, A. J., Grainger, C. M., Young, J. C., Shelp, B. J., \& Lee, E. A. (2010). Impact of postharvest handling on carotenoid concentration and composition in high-carotenoid maize (Zea mays L.) kernels. Journal of Agricultural and Food Chemistry, 58(14), 8286-8292. http://dx.doi. org/10.1021/jf100161r. PMid:20593834.

Cantrell, A., McGarvey, D. J., Truscott, T. G., Rancan, F., \& Böhm, F. (2003). Singlet oxygen quenching by dietary carotenoids in a model membrane environment. Archives of Biochemistry and Biophysics, 412(1), 47-54. http://dx.doi.org/10.1016/S0003-9861(03)00014-6. PMid:12646267.

Cardoso, W. S., Paes, M. C. D., Galvão, J. C. C., Rios, S. A., Guimarães, P. E. O., Schaffert, R. E., \& Borém, A. (2009). Variability of maize genotypes for grain carotenoid composition. Pesquisa Agropecuária Brasileira, 44, 164-173.

DellaPenna, D., \& Pogson, B. J. (2006). Vitamin synthesis in plants: tocopherols and carotenoids. Annual Review of Plant Biology, 57(1), 711-738. http://dx.doi.org/10.1146/annurev.arplant.56.032604.144301. PMid:16669779.

Egesel, C. O., Wong, J. C., Lambert, R. J., \& Rocheford, T. R. (2003). Combining ability of maize inbreds for carotenoids and tocopherols. Crop Science, 43(3), 818. http://dx.doi.org/10.2135/cropsci2003.8180. 
Fong, F., Smith, J. D., \& Koehler, D. E. (1983). Early events in maize seed development: 1-methyl-3-phenyl-5-(3-(trifluormethyl)phenyl)4-(1H)-pyridinone induction of vivipary. Plant Physiology, 73(4), 899-901. http://dx.doi.org/10.1104/pp.73.4.899. PMid:16663339.

Fundação Arthur Bernardes. (2007). Sistema para Análises Estatísticas. Versão 9.1. Viçosa: Fundação Arthur Bernardes.

Janick-Buckner, D., Hammock, D. J., Johnson, J. M., Osborn, J. M., \& Buckner, B. (1999). Biochemical and ultrastructural analysis of the y10 mutant of maize. The Journal of Heredity, 90(5), 507-513. http:// dx.doi.org/10.1093/jhered/90.5.507.

Kean, E. G., Hamaker, B. R., \& Ferruzzi, M. G. (2008). Carotenoid bioaccessibility from whole grain and degermed maize meal products. Journal of Agricultural and Food Chemistry, 56(21), 9918-9926. http://dx.doi.org/10.1021/jf8018613. PMid:18937488.

Kurilich, A. C., \& Juvik, J. A. (1999). Quantification of carotenoid and tocopherol antioxidants in Zea mays. Journal of Agricultural and Food Chemistry, 47(5), 1948-1955. http://dx.doi.org/10.1021/ jf981029d. PMid:10552476.

Mantovani, E. C. (2010) Colheita e pós-colheita. In J. C. Cruz, R. P. Versiani \& M. T. R. Ferreira (Eds.), Cultivo do milho (6th ed., Sistema de Produção, no. 1). Sete Lagoas: Embrapa Milho e Sorgo.

Moura, F. F., Miloff, A., \& Boy, E. (2015). Retention of provitamin a carotenoids in staple crops targeted for biofortification in africa: cassava, maize and sweet potato. Critical Reviews in Food Science and Nutrition, 55(9), 1246-1269. http://dx.doi.org/10.1080/10408 398.2012.724477. PMid:24915386.

Owens, B. F., Lipka, A. E., Magallanes-Lundback, M., Tiede, T., Diepenbrock, C. H., Kandianis, C. B., Kim, E., Cepela, J., MateosHernandez, M., Buell, C. R., Buckler, E. S., DellaPenna, D., Gore, M. A., \& Rocheford, T. (2014). A foundation for provitamin A biofortification of maize: genome-wide association and genomic prediction models of carotenoid levels. Genetics, 198(4), 1699-1716. http://dx.doi.org/10.1534/genetics.114.169979. PMid:25258377.
Pinzino, C., Capocchi, A., Galleschi, L., Saviozzi, F., Nanni, B., \& Zandomeneghi, M. (1999). Aging, free radicals, and antioxidants in wheat seeds. Journal of Agricultural and Food Chemistry, 47(4), 1333-1339. http://dx.doi.org/10.1021/jf980876d. PMid:10563976.

Rodriguez-Amaya, D. B. (2001) A guide to carotenoid analysis in foods (64 p.). Washington, DC: ILSI Human Nutrition Institute.

Rodriguez-Amaya, D. B., \& Kimura, M. (2004). HarvestPlus Handbook for carotenoid analysis (Technical Monograph Series, no. 2). Washington, DC: HarvestPlus. Retrieved from: http://www.harvestplus.org/ content/harvestplus-handbook-carotenoid-analysis.

Schwartz, S. H., Tan, B. C., Gage, D. A., Zeevaart, J. A. D., \& McCarty, D. R. (1997). Specific oxidative cleavage of carotenoids by VP14 of maize. Science, 276(5320), 1872-1874. http://dx.doi.org/10.1126/ science.276.5320.1872. PMid:9188535.

Simkin, A. J., Zhu, C., Kuntz, M., \& Sandmann, G. (2003). Light-dark regulation of carotenoid biosynthesis in pepper (Capsicum annuum) leaves. Journal of Plant Physiology, 160(5), 439-443. http://dx.doi. org/10.1078/0176-1617-00871. PMid:12806770.

Vallabhaneni, R., \& Wurtzel, E. T. (2009). Timing and biosynthetic potential for carotenoid accumulation in genetically diverse germplasm of maize. Plant Physiology, 150(2), 562-572. http:// dx.doi.org/10.1104/pp.109.137042. PMid:19346441.

Wurtzel, E. T. (2004). Genomics, genetics, and biochemistry of maize carotenoid biosynthesis. Recent Advances in Phytochemistry, 38, 85-110.

Xu, J. G., Hu, Q. P., Wang, X. D., Luo, J. Y., Liu, Y., \& Tian, C. R. (2010). Changes in the main nutrients, phytochemicals, and antioxidant activity in yellow corn grain during maturation. Journal of Agricultural and Food Chemistry, 58(9), 5751-5756. http://dx.doi.org/10.1021/ jf100364k. PMid:20345188.

Zhou, X., McQuinn, R., Fei, Z., Wolters, A. M., van Eck, J., Brown, C., Giovannoni, J. J., \& Li, L. (2011). Regulatory control of high levels of carotenoid accumulation in potato tubers. Plant, Cell \& Environment, 34(6), 1020-1030. http://dx.doi.org/10.1111/j.13653040.2011.02301.x. PMid:21388418. 